\title{
Integrating Concept of Entrepreneurship Into Science Education
}

\author{
${ }^{1}$ Muhammad Nizaar \\ ${ }^{1}$ Universitas Muhammadiyah Mataram, Mataram, Indonesia \\ muhammadnizaar@gmail.com
}

\begin{tabular}{|c|c|}
\hline Article Info & Abstract \\
\hline $\begin{array}{l}\text { Article History } \\
\text { Received: July 12, } 2018 \\
\text { Accepted: September 30, } \\
2018 \\
\text { Keywords } \\
\text { Character; } \\
\text { Entrepreneurship; Students; } \\
\text { Science Learning }\end{array}$ & $\begin{array}{l}\text { Science learning should become meaningful and useful experience for the } \\
\text { students to answer problems in daily life, especially economical problems. } \\
\text { Through the integration of science learning and entrepreneurship it is hoped } \\
\text { that entrepreneur character develops in the children's self. The main } \\
\text { components of entrepreneurship consist of three aspects, namely creative } \\
\text { force, sense, and intention. Creative force creates the characters of } \\
\text { innovative, creative, careful, organized, broadening insight, problem solver, } \\
\text { and reflective. Sense aspect creates the characters of confident, want to gain } \\
\text { profit, able to serve, truthful, determined, optimistic, and sharp to chances. } \\
\text { Intention creates the character of brave, risk taking, hard work, cooperative, } \\
\text { responsible, listening to inputs, able to negotiate, discipline, and dynamic. } \\
\text { Science learning integrated with entrepreneurship is required to develop } \\
\text { learning activities yielding comprehensive meaning and benefit. }\end{array}$ \\
\hline $\begin{array}{l}\text { Support by: } \\
\text { do) Crossref }\end{array}$ & This is an open access article under the CC-BY-SA license \\
\hline
\end{tabular}

\section{INTRODUCTION}

Education becomes an important component in determining a nation's civilization. The function of education in a country determines the dignity of its people. Education has to do innovation and adapt with the age development. It needs adaptation and innovation for its many other components, such as the components of economical, social, and cultural.

In the globalization era, Indonesia is faced with some challenges in international trading rivalry as a consequence of the establishment of free trade zone in the ASEAN and Asia Pacific regions. Therefore, variation and innovation of educational patters are required in order to follow educational orientation of the 21st century.

Educational orientation in the 21st century is focused on three aspects such as; critical thinking and problem solving (expert thinking), communication and collaboration (complex communicating), and creativity and innovation (applied imagination and invention) (Trilling \& Fadel, 2009: 49-59). That concept has relationship with the concept of Ki Hajar Dewantara about three learning center (Tri pusat pembelajaran). Where learning surroundings according to Ki Hadjar Dewantara consists of family, school, and community. Those three learning societies have to contain the aspect of educational attainment of the 21st century, such as expert thinking, complex communication, applied imagination and invention.

The three aspects above must be done by the Science teachers so that the students received a knowledge concept that can be done at school, at home and in the society surroundings integrated.

Science learning is a field of study about natural and material phenomena that is acquired through observation, experimentation, and trials. The results are formulated in 
the form of rules, concepts, laws, principles, and theories that can be tested and redeveloped.

When viewed from current science-learning practice, the weakest point of learning at least lies on; first, instructional orientation prefers to the completion of the subject matter rather than the mastery of understanding. This is because teachers do not have enough time to teach. It takes longer time and process to educate students in conditions of significant social, economic, and cultural disparities between regions, between schools, and between families. Disparity is one of the sources of differences in the ability of students in learning.

Second, scientific process as a characteristic of a scientist can't be maximized in learning. This is influenced by the ability and insight of teachers to perform such activities. The scientific process should not be interpreted narrowly as a practicum course, but rather as the process of discovering a more natural concept through maximizing the functionality of students' self-modalities to gain an understanding.

Third, the ability to create and to make innovation of the students is difficult to appear because educators are not fully aware that the learning environment is unlimited. Learning environment as Ki Hajar Dewantara's concept of tripusat are school environment, home, and society. The hope is that these three environments can be involved in the process of learning science so that students are well aware that the object of science study is everywhere. Thus, students will feel that learning science as a necessity.

Another problem that is considered in contrast to science learning is the problem of family economic disparity. Actually, people really hope that sending their children to school can help to improve the economic condition. However, after graduation, the child is faced with difficult conditions to get a job.

Education and economic conditions are two things that affect each other, not opposite. Referring to the opinion of Ozturk (2001: 7) that education is also needed for economic development. There can be no economic development without good education. A balanced education system not only promotes economic development, but also increases productivity, and increases per capita income. The influence of education on economic development is seen in micro level, which is family welfare.

The challenge towards global competition requires schools and science learning practices to be transformed in developing student competence through the integration of science learning with entrepreneurship character. The value of learning in question is the basic value of science learning in the form of scientific processes, knowledge products, and scientific attitudes combined with the character of entrepreneurship.

The authors assessed the need to identify the entrepreneurial character that can be raised in every competence of science learning. Entrepreneurship is one part of the soft skill that needs to be developed as human capital ready to active into the 21st century society. According to Nasution (2016: 149), human capital consists of knowledge, skills and abilities, life experience, and creativity. If entrepreneurship and science learning can be united, it will create useful knowledge for the social and economic life of children when they are at home and in the community. Not just looking for a job, but being able to innovate to create your own jobs.

\section{METHOD}

The method of this article study uses analysis and studies of literature, previous research results, and relevant references. It is expected that the results of this study provide new insights and thinking orientations about the urgency of developing entrepreneurship character in the teaching and learning process of science in schools. 


\section{RESULT}

Integration model of entrepreneurship character and science learning is developed from the nature of science learning concept and entrepreneurship. The integration is seen from the following picture.

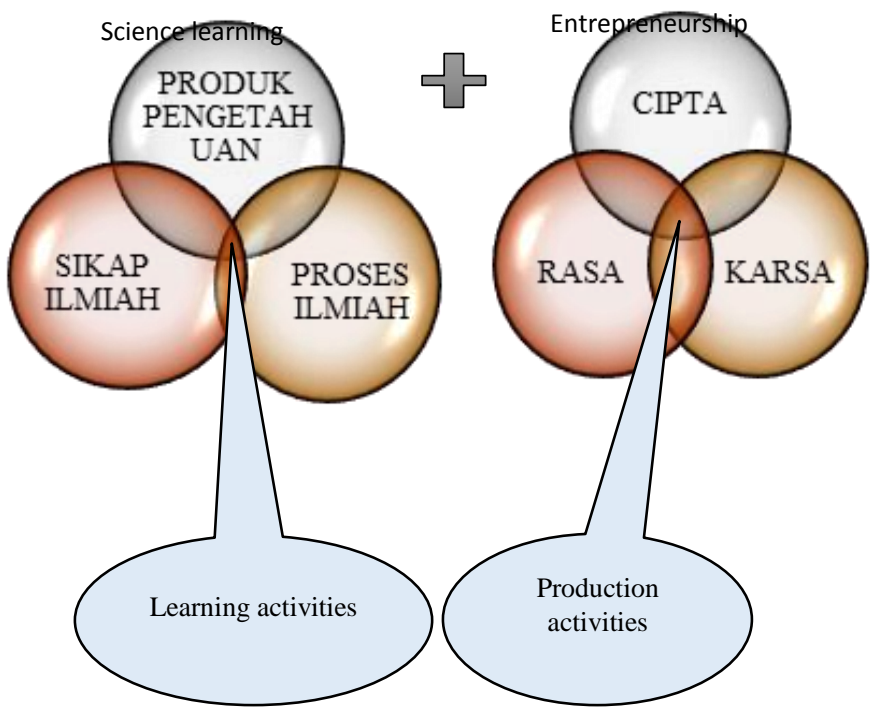

Figure 1: The Integration of Science learning and Entrepreneurship

From the results of this combination, it can be identified various types of entrepreneurship typical characters in students who are born from the tri sakti belajar by Ki Hajar Dewantara.

Table 1: Types of combination character between tri sakti and Entrepreneurship

\begin{tabular}{|c|c|c|}
\hline $\begin{array}{c}\text { Tri Sakti } \\
\text { (Learning) }\end{array}$ & $\begin{array}{l}\text { Character element } \\
\text { (Entrepreneur) }\end{array}$ & Indicator \\
\hline \multirow{7}{*}{$\begin{array}{l}\text { Create / idea } \\
\text { / Knowledge }\end{array}$} & Innovative & Have a new idea, think logically \\
\hline & Creative & Produce a different way, broad perspective \\
\hline & Careful & Preparing with detail, observant in checking \\
\hline & Organized & $\begin{array}{l}\text { Systematic in developing plans, assigning } \\
\text { tasks and functions }\end{array}$ \\
\hline & Widening knowledge & $\begin{array}{l}\text { Curious, get involved in the business } \\
\text { community }\end{array}$ \\
\hline & Problem solver & Find solution ideas, implement solutions \\
\hline & Reflective & $\begin{array}{l}\text { Looking back at the work process, determine } \\
\text { the corrective action }\end{array}$ \\
\hline \multirow{7}{*}{$\begin{array}{l}\text { Feeling / } \\
\text { instinct / } \\
\text { attitude }\end{array}$} & Confident & Proud of work, confidence in business \\
\hline & Want a profit (profit) & $\begin{array}{l}\text { Plan outcome targets, calculate expenses } \\
\text { and income }\end{array}$ \\
\hline & Able to serve & $\begin{array}{l}\text { Focus on customer needs, attract customer } \\
\text { attention }\end{array}$ \\
\hline & Honest & Trustworthy for others, say true things \\
\hline & Determined & $\begin{array}{l}\text { Consistent on purpose, able to manage } \\
\text { stress }\end{array}$ \\
\hline & Optimistic & $\begin{array}{l}\text { Business confidence is achieved, trying to } \\
\text { the maximum }\end{array}$ \\
\hline & Being detail to chance & $\begin{array}{l}\text { Looking for new info, do not stop when there } \\
\text { are obstacles }\end{array}$ \\
\hline
\end{tabular}




\begin{tabular}{|c|c|c|}
\hline \multirow{8}{*}{$\begin{array}{l}\text { Creation / } \\
\text { action /skills }\end{array}$} & Dare to take risk & Do the calculation, dare to make a decision \\
\hline & Work hard & Strive earnestly, strong beliefs \\
\hline & Cooperative & $\begin{array}{l}\text { Believe in partners, division of tasks and } \\
\text { functions }\end{array}$ \\
\hline & Responsible & Face every risk, have control over conditions \\
\hline & Willing to hear feedback & $\begin{array}{l}\text { Be patient with criticism, accept positive } \\
\text { suggestions }\end{array}$ \\
\hline & Able to negotiate & $\begin{array}{l}\text { Able to discuss, easy-to-understand } \\
\text { language }\end{array}$ \\
\hline & Discipline & Timeliness of action, obedience rules \\
\hline & Move dynamically & Responsive to change, make quick decisions \\
\hline
\end{tabular}

The aspect of creative force character leads to scientific products of science that is insight and knowledge about utilizing environmental conditions as a source of entrepreneurship that promotes the principles of environmental sustainability. Aspects of character sense leads to the scientific attitude of students as a scientist who put forward the principle of curiosity and oriented to economic profit. The aspect of the initiative character leads to work processes and efforts that remain to the scientific principles and courage in taking a decision and action

In its application, entrepreneurship integration model in science learning process can be done through various materials, for example on the following environment material syntax.

\begin{tabular}{|l|l|}
\hline \multicolumn{1}{|c|}{ Phase } & \multicolumn{1}{c|}{ Activity } \\
\hline $\begin{array}{l}\text { Introduction } \\
\text { phase }\end{array}$ & $\begin{array}{l}\text { Classroom preparation, learning objectives and indicators, } \\
\text { apperception activities }\end{array}$ \\
\hline Main phase & $\begin{array}{l}\text { Phase of Preparation: Directing group and work rules } \\
\text { Product-making phase: reuse, reduce, and recycle } \\
\text { Phase of marketing plan: simple SWOT analysis, partnership / proposal } \\
\text { plan. }\end{array}$ \\
\hline Closing phase & Appreciation of success, enrichment, feedback \\
\hline
\end{tabular}

\section{Science Learning Community}

The development of science and technology that emphasizes the aspect of meaningfulness and the change of life orientation of society that leads to the fulfillment of economic needs as the impact of global economic competition hence science learning need to be directed to science berkemajuan orientation. Berkemajuan means able to benefit for the sustainability and welfare of students in the future which will come with regard to the environment.

Good schools and learning are places where children learn valuable things to create a strong foundation in later life, as well as a place where children develop a desire to learn more. Particularly, a good school reflects the reality of life in an orderly society and allows personal expression within the framework of social responsibility (Yatvin, 2012).

Thus, science learning that is progressive is a science lesson that is adaptive to the demands of the times. Adaptive develop aspects of the study, modify the scientific process without reducing the substance, as well as produce a work product that is worth the benefits for life, not just the concept and theory but also the real effort needed by the public. 
Observing these demands then aspects that need to be considered again by the educators is the importance of maximizing the learning environment. According to Ki Hajar (Choiri, 2017: 89) explained that the learning environment consists of:

a. School environment; such as teachers, administration, principals. A good learning environment is a learning environment that is conducive, clean, comfortable, and free from psychological pressure.

b. Community environment; an environment in which the child relates directly to others freely. Can be seen from the two spec is the atmosphere of the relationship between the people in it and the condition of the physical environment, such as cleanliness, slums, sanitation, etc.

c. Family environment; is the first place of education. The family is like an open school where everything is learned, from waking up to getting out of the house. Surely what is experienced in the house will be carried away and affect the form of child behavior in school and in the community.

\section{The Nature of Entrepreneurship for Science Lesson}

In The World Economic Forum report (2009: 14) entrepreneur is defined as an individual doing business and entrepreneurship is the business process undertaken. In the report also added the term entrepreneurial and entrepreneurial ecosystem. Entrepreneurial means attitudes, skills, and behaviors. While entrepreneurial ecosystem is a role of society in the form of policy and environmental conditions that must be designed to support entrepreneurship.

Schumpter (Bula, 2012: 82) defines entrepreneurship from an economic perspective focusing on new economic opportunities and the introduction of new ideas in the market by identifying opportunities, gathering needed resources, implementing action plans, and earning profits.

From the definition above, it is shown that entrepreneurship is an entrepreneurial activity that involves various resources through a plan and a measurable process to achieve a goal of economic benefits.

Entrepreneurial activities for vocational and non-vocational students are of course different from the aspect of the type of product produced, but essentially the same. Equally build business systems, work organization, and calculations in conducting business. The different types of business activities of vocational students and nonvocational students (on science subjects) are presented in the following table.

Table 2: The Difference Type of Vocational and Non-Vocational Entrepreneur (Field of Science)

\begin{tabular}{|c|c|}
\hline Vocational & Non-Vocational (Science) \\
\hline $\begin{array}{l}\text { Welding business, shop business, } \\
\text { photography services, electronic } \\
\text { services (computer, TV, etc.), makeup } \\
\text { and convection business, food business } \\
\text { (catering), cinema, machine and } \\
\text { automotive workshop, construction } \\
\text { services, multimedia services, electricity, } \\
\text { etc. }\end{array}$ & $\begin{array}{l}\text { Handicraft from garbage or used goods, } \\
\text { garbage bank in schools, children's toys } \\
\text { from used goods, compost business } \\
\text { (organic), ornamental plants and plant } \\
\text { breeding, fish pond business, herbarium } \\
\text { and insectariums, biotechnology tempe and } \\
\text { tauco, }\end{array}$ \\
\hline
\end{tabular}

Entrepreneurial activities on science subjects are activities to support the understanding of concepts as well as the application form of the concept. This activity 
will feel more meaningful and useful because students are actively involved and gain economic benefits.

\section{Supporting Policy}

From the results of World Economic Forum 2009, entrepreneurial ecosystem is a system built to support business activities in the form of structured policy. The system in question is:

1) Government: related to policy support and funding, namely international, national, regional and local governments;

2) educational institutions: relating to changes in rules, policies, systems and devices in an educational institution, namely primary and secondary schools, high schools, and informal institutions such as NGOs and foundations;

3) Business actors: related business partners and entrepreneurs, ie entrepreneurs, large companies and developing companies.

Referring to variant of schools in Indonesia, vocational and non-vocational, entrepreneurial ecosystem needs to be formed as follows.

Table 3: Entrepreneurial Ecosystem for Non-Vocational School

\begin{tabular}{|c|c|c|}
\hline \multicolumn{3}{|c|}{ Entrepreneurial Ecosystem } \\
\hline Government & $\begin{array}{c}\text { Education department \& } \\
\text { School Principal }\end{array}$ & $\begin{array}{c}\text { Partner (Entrepreneur / } \\
\text { Location) }\end{array}$ \\
\hline $\begin{array}{l}\text { Create legal umbrella } \\
\text { and budget allocations } \\
\text { for business models } \\
\text { that want to be } \\
\text { developed in non- } \\
\text { vocational schools }\end{array}$ & $\begin{array}{l}\text { Identify efforts that can be } \\
\text { developed from the } \\
\text { integration model with the } \\
\text { subjects as well as build } \\
\text { partnerships }\end{array}$ & $\begin{array}{l}\text { Providing business space and } \\
\text { partnership as a means of } \\
\text { education and promotion }\end{array}$ \\
\hline
\end{tabular}

Entrepreneurs will thrive in an environment where stakeholders play a key role. Educational institutions are central in shaping attitudes, skills and behaviors of children. The main thing is that the perpetrators can benefit economically from the built entrepreneurial ecosystem. The key thing is a partnership and cooperation that can reach each other.

\section{Entrepreneur Character in Science Learning}

According to Zimmerer (Buchari Alma, 2013: 67), entrepreneur profile description is; "This is the profile of the entrepreneurship that drives the growth of the American economy after the Second World War. This can be understood under the character of entrepreneurship is a positive character that can build the civilization of the economy of society.

There are many entrepreneurial characters that can be taken from entrepreneurship activities. Almost all entrepreneurs explain about the types of characters in accordance with their respective thoughts.

Referring to the concept of entrepreneurship character can be drawn a connecting line with the concept of tri sakti soul proposed by Ki Hajar Dewantara. According to Ki Hajar Dewantara (1977: 451-456) three powers of soul (tri sakti) in human education are creative force (cipta), feeling (rasa), and willingness (karsa).

Cipta is the power of reasoning and reasoning in the quest for truth by comparing the state so that it can be determined differences and equations, truths and confusion 
Rasa (personal) is any gesture of the heart that causes a person to decide whether or not willing, happy or hard, embarrassed or proud, sad or happy, satisfied or disappointed. In this case the heart is the one who feels, not the mind. Everyone has his own conception in accordance with his acceptance of environmental conditions.

Karsa or willingness (behavior) always arise aside and as if the fruit of thoughts and feelings. Will is a continuation of the lusts that exist in the human psyche but has been considered by the mind and refined by feelings. Will is the starting point of all actions or deeds.

Witjaksono (1995: 32) mentioned that cipta, rasa, and karsa called as entrepreneurial trilogy. Thus, it can be understood that there is a similarity between the concepts of entrepreneurship trilogy by Witjaksono with the concept of tri sakti jiwa by Ki Hadjar Dewantara. However, it differs from the concept of the result. Entrepreneurship trilogy gave birth to production activities (works) while tri sakti gave birth to learning activities.

The two concepts need to be integrated into science learning to achieve more meaningful and useful learning outcomes. According to Achor et al (2013: 111) there must be a model of entrepreneurship process integration in the science of learning as the spirit of integration of religious values and virtue improvement values that are almost required on all subjects in school.

Research conducted by Cepni (2017: 56) on the use of modules that integrate entrepreneurship with science learning gave birth to risk taking, seeing the opportunity, being innovative, self-confidence, and emotional intelligence.

To achieve ideal learning outcomes, the role of the social environment is very influential. According to Suherman (2010: 60) there are four supporting components, namely (1) educational institutions can become business incubators for students, (2) institutional leaders should be mediators with partners, (3) teachers, masters, friends, and communities support, (4) supported by business partners.

Implementing this integration concept will have implications on the learning process that is able to involve the functioning of school environment, home, and community environment through meaningful entrepreneurial activities.

\section{CONCLUTION}

The writer sincerely thanks the experts who have helped to formulate this concept so that it is readable for readers. Special thanks go to Prof. Irene, Prof. Sukirno, and Prof. Djukri who gave the writer direction and motivation so that this article can be arranged.

\section{REFERENCE}

[1] Achor, et al. (2013). "The Need to Integrate Entrepreneurship Education into Science Education Teachers' Curriculum in Nigeria." Journal of Science \& Vocational Education (JSVE), Vol. 7 September 2013.

[2] Buchari Alma. (2013). "Kewirausahaan (Edisi Revisi)."Bandung: Alfabeta.

[3] Bula, Hannah Orwa. (2012). "Evolution and Theories of Entrepreneurship: A Critical Review on the Kenyan Perspective". International Journal of Business and Commerce. Vol. 1 No.11 Pg. 81-96.

[4] Cepni, Salih et al. (2017). "The Effect of Entrepreneurship Education Modules Integrated with Science Education on the Entrepreneurial Characteristics of PreService Science Teachers." Journal Socialinis Darbas. Vol. 15 February 2017. ISSN online 2029-2775 p. 56-85.

[5] Choiri, Moh. Miftahul. (2017). "Upaya memanfaatkan sumber belajar sekitar sebagai sumber belajar anak". Jurnal Refleksi Edukatika. Vol. 8 No. 1. Pg. 92-101. 
[6] Ki Hajar Dewantara. (1977). "Karya Ki Hajar Dewantara Bagian Pertama: Pendidikan." Yogyakarta: Majlis Luhur Persatuan Taman Siswa.

[7] Martin, Catalin \& Iucu, Romita B. (2013). "Teaching entrepreneurship to educational sciences students."Procedia - Social and Behavioral Sciences 116 (2014). 5 th World Conference on Educational Sciences - WCES 2013.

[8] Nasution, Arman Hamkim. (2016). "Creative and Innovation (Thinking Key Success For Young Proffesional)."Yogyakarta: Andi.

[9] Ozturk, Ilhan. (2001). "The role of education in economic development". Journal of Rural Development and Administration. Vol XXXIII (1) pp. 39-47 http://mpra.ub.unimuenchen.de/9023/ (diunduh 10 Maret 2018, 08.26).

[10] Suherman, Eman. (2010). "Desain Pembelajaran Kewirausahaan". Bandung: Alfabeta.

[11] Trilling, Bernie, Fadel, Charles. (2009). "21 st Century Skill”. United States of America: Jossey-Bass

[12] Volkmann, Christine, Bergische, et al., (2009). "Educating the Next Wave of Entrepreneurs: Unlocking entrepreneurial capabilities to meet the global challenges of the 21st Century (A Report of the Global Education Initiative Report)". Switzerland: World Economic Forum.

[13] Witjaksono, M. 1995. Kewirausahaan untuk Koperasi. Malang: Lima Sekawan.

[14] Yatvin, Joanne. (2012). "Sekolah yang baik adalah sekolah yang efektif". https://www.washingtonpost.com/blogs/answer-sheet/post/the-differencebetween-good-schools-and-effectiveschools/2012/01/31/gIQAlQIlsQ blog.html?utm term=.d6833c8fbd0b. Diakses pada 21 April 2018 